\title{
EMISSION DUE TO MOTOR GASOLINE FUEL IN RECIPROCATING LYCOMING 0-320 ENGINE IN COMPARISON TO AVIATION GASOLINE FUEL
}

\author{
Yunenthiran Rajendran, Rahmat Mohsin*
}

\author{
Faculty of Chemical and Energy Engineering, Universiti Teknologi Malaysia (UTM), 81310 UTM, Johor, Malaysia. \\ *Corresponding author Email: rahmat@utm.my
}

This is an open access article distributed under the Creative Commons Attribution License, which permits unrestricted use, distribution, and reproduction in any medium, provided the original work is properly cited

\section{ARTICLE DETAILS}

\section{Article History:}

Received 10 May 2018 Accepted 6 Jun 2018 Available online 10 July 2018

\section{ABSTRACT}

Piston-powered aircrafts rely on 100 low lead (100LL) Aviation Gasoline (AVGAS) for safe operation. AVGAS has high levels of Tetraethyl Lead (TEL). TEL is an additive which is added in aviation fuels to assist in anti-knocking. The main reason for continuation of TEL as an additive in AVGAS is because aircraft engines are prone to engines knock when operate at higher power settings and temperatures. TetraEthyl Lead (TEL) or Plumbum (Pb), which is the additive of AVGAS, for octane boosting and valve recession avoidance, can cause serious health impacts. One of the possible technique to eliminate the effect of $\mathrm{Pb}$ emissions caused by general aviation was to make unleaded Motor Gasoline (MOGAS) accessible as another option to leaded AVGAS for the use in reciprocating aviation engines. The unleaded MOGAS has relatively lower octane rating compared to leaded AVGAS. Due to knocking and engine parameter performance, utilization of a fuel with too low of an octane rating is a risk. Besides, numerous gasses are produced as by product of combustion as a result of emission from aviation engines. In this study, a full scale engine emission due to locally available unleaded MOGAS fuels are determined and compared to the typical leaded AVGAS used. This ground level emission tests are performed by evaluating different fuels on emissions from a full scale Lycoming 0-320-B2A reciprocating engine. The fuels to be tested in this study are 100 LL AVGAS, RON100 MOGAS, RON97 MOGAS, and RON95 MOGAS. Each of this fuel is tested at a time in Lycoming 0-320-B2A reciprocating engine and the data for emission of of exhaust gases CO, NOx and HC, were measured by an emission analyser (EMS 5002) and recorded. Although the emission of both AVGAS and MOGAS are moreover the same it is expected that that MOGAS burns cleanly and minimal combustion chamber deposits are produced in the engine.

\section{KEYWORDS}

Emission, reciprocating engine, octane rating, aviation gasoline (AVGAS), motor gasoline (MOGAS).

\section{INTRODUCTION}

Air transportation has been foremost mode of connecting role player in business supply chain and catalyst for tourism industry. Globally around 230,000 piston-powered aircrafts rely on 100 low lead (100LL) Aviation Gasoline (AVGAS) for safe operation [1]. AVGAS is a specially blended grade of gasoline for use in aircraft engines of the piston type. Aircrafts using AVGAS operate on higher compression ratio engines, which thus requires the utilization of high octane gasoline. AVGAS is for use in aircraft engines of the piston type with distillation range normally within $30^{\circ} \mathrm{C}$ and $200^{\circ} \mathrm{C}$ [2]. AVGAS has high levels of Tetraethyl Lead (TEL). TEL is an additive which is added in aviation fuels to assist in anti-knocking. Main reason of TEL continuation as an additive in AVGAS is because aircraft engines are prone to engines knock when operate at higher power settings and temperatures [3].

TetraEthyl Lead (TEL) or Plumbum (Pb), which is the additive of AVGAS, for octane boosting and valve recession avoidance, can cause serious health impacts, including neurological effects in children that prompt behavioral issues, learning deficiencies and lowered IQ. Pb concentrations of 10 micrograms per deciliter or more has been identified as a "level of concern" to human health by the The Centers for Disease Control (CDC) and the World Health Organization (WHO) [4].

Recently, the rate of aviation fuel has multiplied sharply and a few shortages have arisen. Besides, numerous gasses are produced as by product of combustion as a result of emission from aviation engines. Even though aviation's environmental impact is not restrained to emissions from aircraft, these emissions represent the largest challenge. One of the possible technique to eliminate the effect of $\mathrm{Pb}$ emissions caused by general aviation was to make unleaded Motor Gasoline (MOGAS) accessible as another option to leaded AVGAS for the use in reciprocating aviation engines.

Both MOGAS and AVGAS are evaluated based on the octane number in respective fuels. However those fuels uses different octane estimation techniques. AVGAS octane number is characterized as Motor Octane Number (MON) while MOGAS octane number is characterized by the antiknock index (AKI). Ethanol contained in MOGAS is not appropriate for use in aviation due to materials compatibility, volatility, and phase separation issues thus, for safe operations in the air zero-ethanol MOGAS is mandatory [5].

Other than engine compatibility issues on the usage of MOGAS in Aviation, emissions profile of MOGAS when used in reciprocating aviation engines raise concerns. Emissions from aircraft piston engines not considered as a significant problem in comparison to the total emissions, but small to no concerns, emissions from piston engine aircrafts have not red-flagged any issues so far and globally there have not been any efforts to consider emission certification for piston engine aircrafts because data about piston engine aircraft emissions performance is almost non-existent [6]. Greenberger, in her foreword for the Exhaust Emissions from In-Use General Aviation Aircraft ACRP 164 Research Report, mentioned that, emissions information for piston-powered aircrafts, either do not exist or have not been independently verified. This can cause an underestimation or over-estimation of piston-powered aircraft emissions and makes it difficult for general aviation (GA) to exactly quantify the emissions 
inventories [7]. Comparative emissions measurements to quantify the emissions profile of both AVGAS and MOGAS in reciprocating aviation engine are crucial as it gives proper picture of the real scenario of MOGAS usage in aviation as far as environmental aspects are concerned.

Up to now, there have only been few emissions data available for aircraft piston engines. This report tries to fill this gap of knowledge in a comprehensive approach. It is expected that as the regular leaded grade of autogas is phased out and the lead in leaded fuel is reduced, then more aircraft will be using unleaded autogas in the engines.

\section{EXPERIMENTAL}

The experimental activity carried out within this study is focused on the evaluation of different fuels on emissions from Lycoming 0-320-B2A engine. By keeping some factor such as complexity of the testing, funds availability, field-expert availability and scale of the research scope in mind this experiment was conducted with a practical and doable methodology.

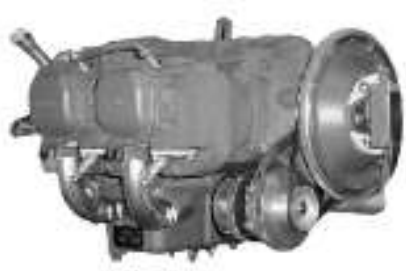

(a)

\subsection{Evaluated Fuels}

In order to evaluate the effects that different fuels may have on the selected Lycoming engine, in terms engine out emissions, experimental tests are to be performed using the four following fuels:

\section{- $\quad 100$ LOW LEAD AVIATION GASOLINE (AVGAS) \\ - $\quad$ PETRON'S RON 95 MOGAS \\ - $\quad$ PETRON'S RON 97 MOGAS \\ - $\quad$ PETRON'S RON 100 MOGAS}

\subsection{Test Engine Set-up}

The test engine (Lycoming $0-320-\mathrm{B} 2 \mathrm{~A}$ reciprocating engine) is set-up in the laboratory in order to conduct the engine emission test on different fuels. Lycoming 0-320-B2A reciprocating engine will be used as the test engine which is a four-cylinder, direct drive and horizontally opposed, air cooled engine.

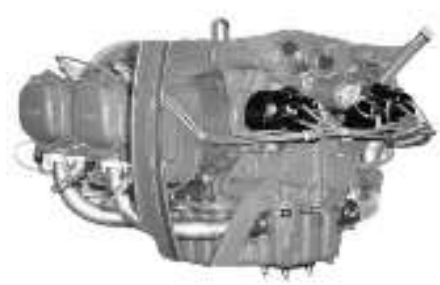

(b)

Figure 1: Typical 0-320 Series (a) 3/4 Right Front View (b) 3/4 Left Front View

The test engine will be mounted on a DYNOmite dynamometer. The data from engine testing will be obtained from this dynamometer. DYNOmite "Pro" Data Acquisition Subsystem is a 28-channel configuration which monitors four frequencies which includes engine RPM, speed, air and fuel flow, several millivolt thermocouple and strain gauge inputs for EGTs and torque load cells, plus an array of 0-5 volts ones for handling pressures and similar transducers [8]. The dynamometer that connected to the test
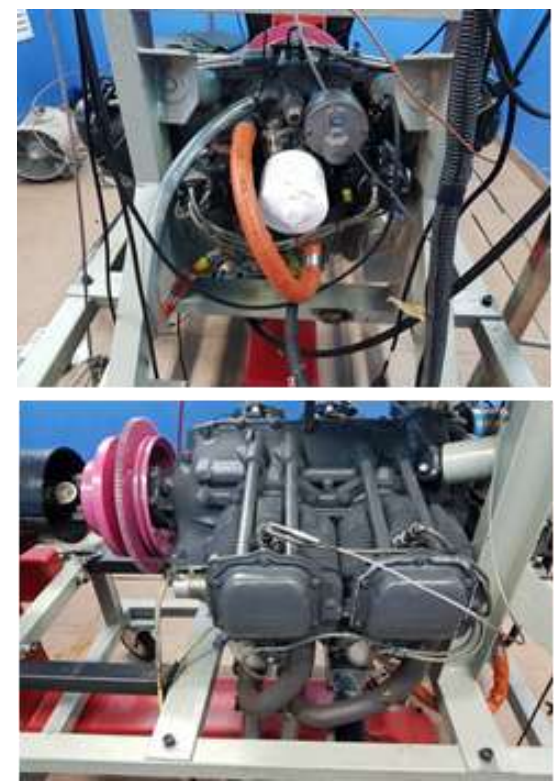

Figure 2: Engine set-up with Dynamometer

\subsection{Engine Emission Testing}

The selected MOGAS and AVGAS fuels are tested in Lycoming 0-320-B2A reciprocating engine to study on their emission characteristics. 100LL AVGAS is chosen as the reference AVGAS as it is the most common type of AVGAS used in aircraft engines worldwide. The fuels chosen to represent MOGAS are RON100, RON97, and RON95 because this are the fuels that can be find easily in the market. The difference in this MOGAS fuels are the octane rating.

The testing methodology is based on ASTM 6522 (standard test method for determination of nitrogen oxides, carbon monoxides from

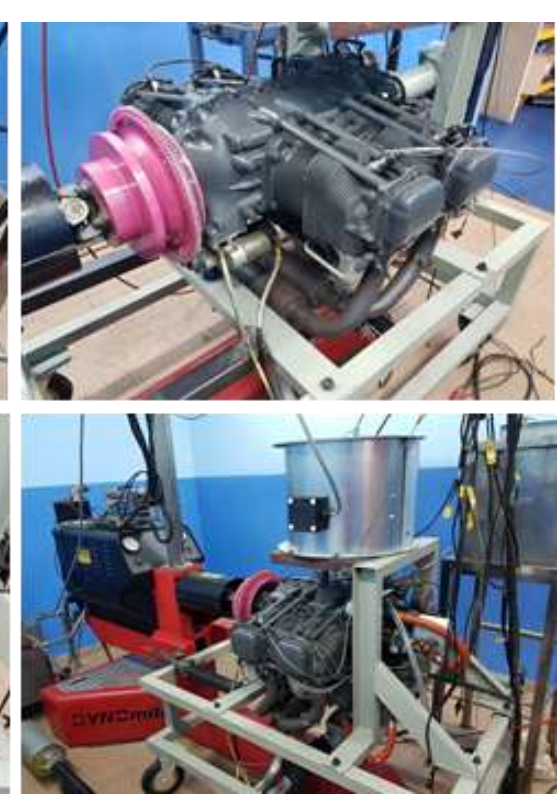

engine plays an important role in this experiment as it ensures monitoring the engine parameters such as engine speed (RPM), brake horsepower (BHP), fuel flow, engine shaft torque, exhaust gas temperatures [8]. Necessary sensors such are also connected to the test engine in order to monitor every single parameters of the test engine for a smooth operation. Engine set-up with Dynamometer are as follows 
Table 1: Gas analyser's specifications [9]

\begin{tabular}{|lcccc|}
\hline \multicolumn{5}{c|}{ Gas analysers' specification } \\
\hline Species & Measured Unit & Range & Resolution & Accuracy \\
$\mathbf{C O}_{2}$ & $\%$ & $0-20 \%$ & $0.30 \%$ & \pm 1 \\
$\mathbf{H C}$ & $\mathrm{ppm}$ & $0-24,000 \mathrm{ppm}$ & $4 \mathrm{ppm}$ & \pm 1 \\
$\mathbf{C O}$ & $\%$ & $0-10 \%$ & $0.06 \%$ & \pm 1 \\
$\mathbf{O}_{2}$ & $\%$ & $0-25 \%$ & $0.10 \%$ & \pm 1 \\
$\mathbf{N O}_{\mathbf{x}}$ & $\mathrm{ppm}$ & $0-5000 \mathrm{ppm}$ & $1 \mathrm{ppm}$ & \pm 1 \\
\hline
\end{tabular}

Each time a different fuel is selected or the engine power setting is changed; conditions shall be allowed to become stable and time for fuel to enter engine and for conditions to stabilize. The waiting period is minimum of 2 minutes.

\section{RESULTS AND DISCUSSION}

The test engine (Lycoming 0-320-B2A reciprocating engine) performance in response to RON95 MOGAS, RON97 MOGAS and RON100 MOGAS gasoline in comparison to 100LL AVGAS was inspected with various

Table 3.1 Exhaust Gas Emission using RON95 MOGAS

\begin{tabular}{|l|l|l|l|}
\hline $\begin{array}{c}\text { Pollutant } \\
\text { Speed } \\
(\mathbf{R P M})\end{array}$ & $\begin{array}{c}\mathrm{HC} \\
(\mathbf{P P m})\end{array}$ & $\begin{array}{c}\text { NOx } \\
(\mathbf{P P m})\end{array}$ \\
\hline $\mathbf{1 0 0 0}$ & 6.97 & 550.67 & 11.00 \\
\hline $\mathbf{1 1 0 0}$ & 6.99 & 554.00 & 11.33 \\
\hline $\mathbf{1 2 0 0}$ & 6.97 & 536.67 & 11.33 \\
\hline $\mathbf{1 3 0 0}$ & 7.00 & 536.67 & 11.33 \\
\hline 1400 & 6.97 & 532.33 & 11.67 \\
\hline 1500 & 7.02 & 535.33 & 11.67 \\
\hline 1600 & 7.06 & 542.33 & 11.67 \\
\hline 1700 & 7.13 & 546.33 & 12.23 \\
\hline 1800 & 7.15 & 548.33 & 12.23 \\
\hline 1900 & 7.28 & 560.33 & 12.23 \\
\hline 2000 & 7.37 & 572.00 & 12.33 \\
\hline 2100 & 7.55 & 572.00 & 12.67 \\
\hline 2200 & 7.55 & 563.00 & 12.33 \\
\hline 2300 & 7.33 & 561.00 & 12.67 \\
\hline 2400 & 7.30 & 555.33 & 12.67 \\
\hline 2500 & 7.16 & 543.33 & 12.00 \\
\hline & & & \\
\hline
\end{tabular}

Table 3.2 Exhaust Gas Emission using RON97 MOGAS

\begin{tabular}{|c|c|c|c|}
\hline $\begin{array}{c}\text { Pollutant } \\
\begin{array}{c}\text { Speed } \\
\text { (RPM) }\end{array}\end{array}$ & $\begin{array}{c}\text { CO } \\
(\%)\end{array}$ & $\begin{array}{c}\text { HC } \\
(\mathrm{ppm})\end{array}$ & $\begin{array}{c}\text { NOs } \\
(\mathrm{pPm})\end{array}$ \\
\hline 1000 & 7.34 & 571.67 & 12.00 \\
\hline 1100 & 7.34 & 572.67 & 12.33 \\
\hline 1200 & 7.45 & 572.00 & 12.33 \\
\hline 1300 & 7.46 & 571.00 & 12.67 \\
\hline 1400 & 7.47 & 570.67 & 12.67 \\
\hline 1500 & 7.47 & 569.33 & 12.67 \\
\hline 1600 & 7.48 & 569.00 & 12.67 \\
\hline 1700 & 7.48 & 568.00 & 12.67 \\
\hline 1800 & 7.47 & 566.33 & 12.67 \\
\hline 1900 & 7.49 & 558.00 & 12.67 \\
\hline 2000 & 7.49 & 554.67 & 12.67 \\
\hline 2100 & 7.51 & 545.67 & 12.67 \\
\hline 2200 & 7.51 & 537.67 & 12.67 \\
\hline 2300 & 7.38 & 523.67 & 13.00 \\
\hline 2400 & 7.28 & 508.67 & 12.67 \\
\hline 2500 & 7.28 & 503.33 & 12.33 \\
\hline
\end{tabular}

engine speeds (RPM). The exhaust emission of the test engine using various fuels was determined. The results were derived directly from the measured experimental data. In order to obtain a better and accurate results 3 readings was taken for each evaluated fuel and the average value for exhaust emission gases for each fuel was calculated. This average calculated results was later used to plot the findings. The unburned hydrocarbons (HC) and nitrogen oxides (NOx) was measured in parts per million (ppm) while carbon monoxide (CO) is measured in percentage (\%). The obtained results for average of 3 runs are as in Tables 3.1 to 3.3.

Table 3.3 Exhaust Gas Emission using RON100 MOGAS

\begin{tabular}{|c|c|c|c|}
\hline $\begin{array}{c}\text { Pollutant } \\
\text { Speed } \\
(\text { RPM) }\end{array}$ & $\begin{array}{c}\text { CO } \\
(\%)\end{array}$ & $\begin{array}{c}\text { FC } \\
(\mathrm{PPm})\end{array}$ & $\begin{array}{c}\text { NO } \\
(\mathrm{PPm})\end{array}$ \\
\hline $\mathbf{1 0 0 0}$ & 7.57 & 748.67 & 9.00 \\
\hline $\mathbf{1 1 0 0}$ & 7.59 & 755.33 & 9.00 \\
\hline $\mathbf{1 2 0 0}$ & 7.61 & 770.67 & 9.33 \\
\hline $\mathbf{1 3 0 0}$ & 7.63 & 772.67 & 9.67 \\
\hline 1400 & 7.64 & 773.33 & 10.00 \\
\hline 1500 & 7.66 & 773.33 & 10.00 \\
\hline 1600 & 7.68 & 765.00 & 10.33 \\
\hline 1700 & 7.7 & 759.00 & 10.33 \\
\hline 1800 & 7.72 & 758.67 & 10.33 \\
\hline 1900 & 7.74 & 736.67 & 10.67 \\
\hline 2000 & 7.77 & 707.33 & 10.67 \\
\hline 2100 & 7.81 & 684.00 & 11.67 \\
\hline 2200 & 7.84 & 671.33 & 12.00 \\
\hline 2300 & 7.77 & 639.33 & 12.33 \\
\hline 2400 & 7.66 & 619.67 & 12.33 \\
\hline 2500 & 7.66 & 604.00 & 11.67 \\
\hline
\end{tabular}

Table 3.4 Exhaust Gas Emission using Standard 100LL AVGAS

\begin{tabular}{|c|c|c|c|}
\hline $\begin{array}{c}\text { Pollutant } \\
\text { Speed } \\
\text { (RPM) }\end{array}$ & $\begin{array}{l}\text { CO } \\
(\%)\end{array}$ & $\begin{array}{c}\text { HC } \\
(\mathrm{ppm})\end{array}$ & $\begin{array}{l}\mathrm{NO}_{\mathrm{x}} \\
\text { (ppm) }\end{array}$ \\
\hline 1000 & 8.85 & 833.33 & 6.95 \\
\hline 1100 & 8.86 & 839.67 & 6.99 \\
\hline 1200 & 8.96 & 839.67 & 7.13 \\
\hline 1300 & 8.96 & 841.00 & 7.33 \\
\hline 1400 & 8.97 & 844.00 & 7.33 \\
\hline 1500 & 8.97 & 847.00 & 7.33 \\
\hline 1600 & 8.97 & 851.00 & 7.33 \\
\hline 1700 & 8.97 & 858.00 & 7.33 \\
\hline 1800 & 8.98 & 857.67 & 7.44 \\
\hline 1900 & 8.99 & 857.33 & 7.67 \\
\hline 2000 & 9.04 & 852.33 & 7.67 \\
\hline 2100 & 9.10 & 853.67 & 7.67 \\
\hline 2200 & 9.25 & 851.67 & 7.81 \\
\hline 2300 & 9.15 & 852.33 & 8.00 \\
\hline 2400 & 9.02 & 846.33 & 7.67 \\
\hline 2500 & 9.02 & 826.00 & 7.33 \\
\hline
\end{tabular}

Figures 3.1 to 3.3 illustrate the measured exhaust emissions of carbon monoxide (CO), unburned hydrocarbons (HC) and nitrogen oxides (NOx) from RON95 MOGAS, RON97 MOGAS and RON100 MOGAS operations with in all test conditions in comparison with 100LL AVGAS. 


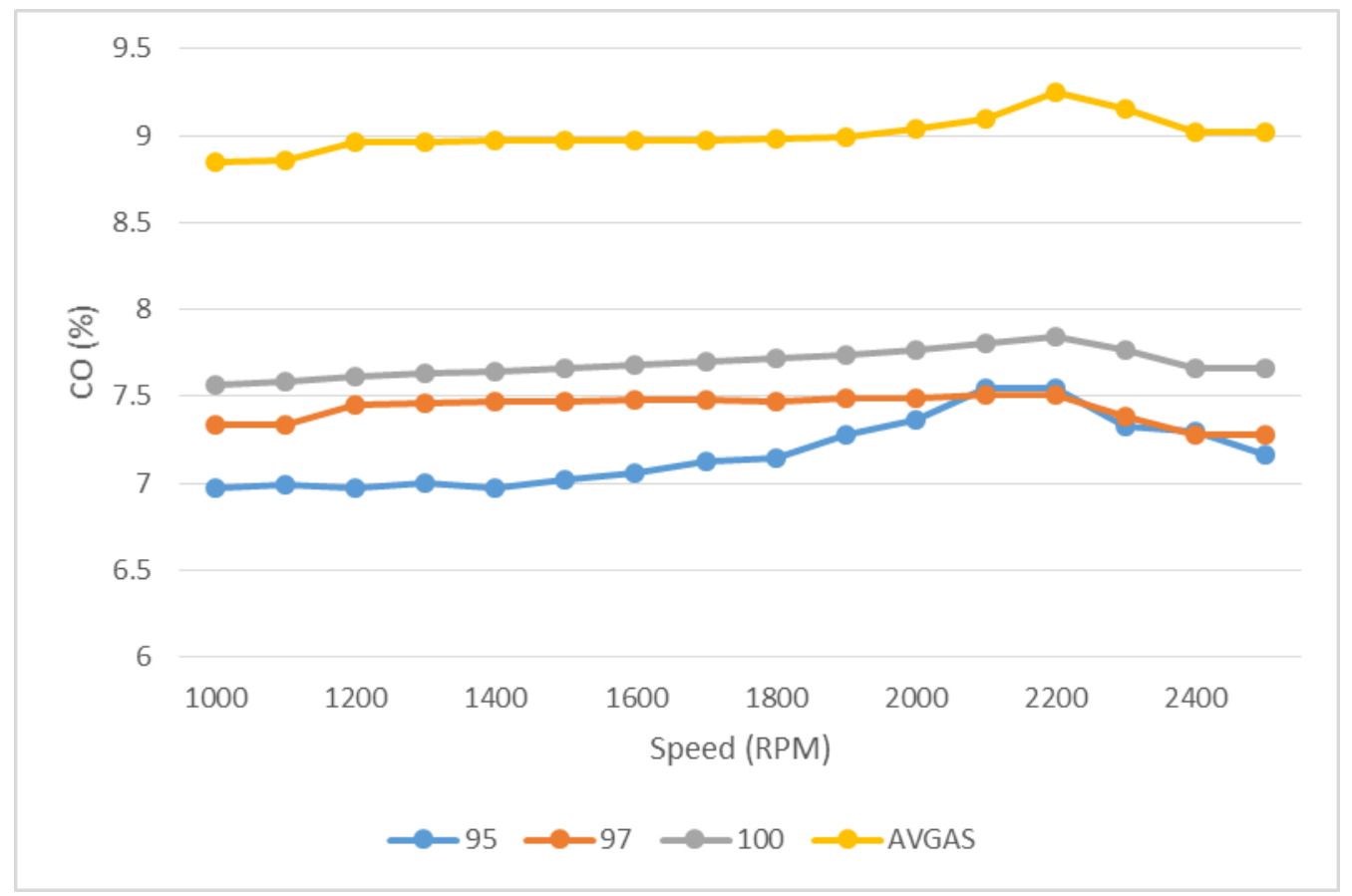

Figure 3.1 Variation of carbon monoxide CO) emission with engine speed

Figure 3.1 shows engine speed versus variations in the $\mathrm{CO}$ emissions. It was observed that there was an increase in $\mathrm{CO}$ emissions with an increase in the engine speed. Then, the $\mathrm{CO}$ emissions were reduced as the speed keeps on increasing. This shows that $\mathrm{CO}$ emissions are relatively constant with engine speed, except at cruise condition. $\mathrm{CO}$ emission increases from idle to taxi, to take-off, and then to cruise. It is noticed that $\mathrm{CO}$ emission is due to incomplete combustion of the fuel.
The use of RON95 slightly reduced the $\mathrm{CO}$ emissions compared to the other RON fuels. Regard to the fact that the emission of $\mathrm{CO}$ depends more on the engine design, the experiment to compare the CO emissions with RON100 to those of RON97 and RON95, and discovered that the CO emissions from RON100 was higher than RON97 and RON95. In the other hand, standard 100LL AVGAS generates the highest CO exhaust gas for aviation engine.

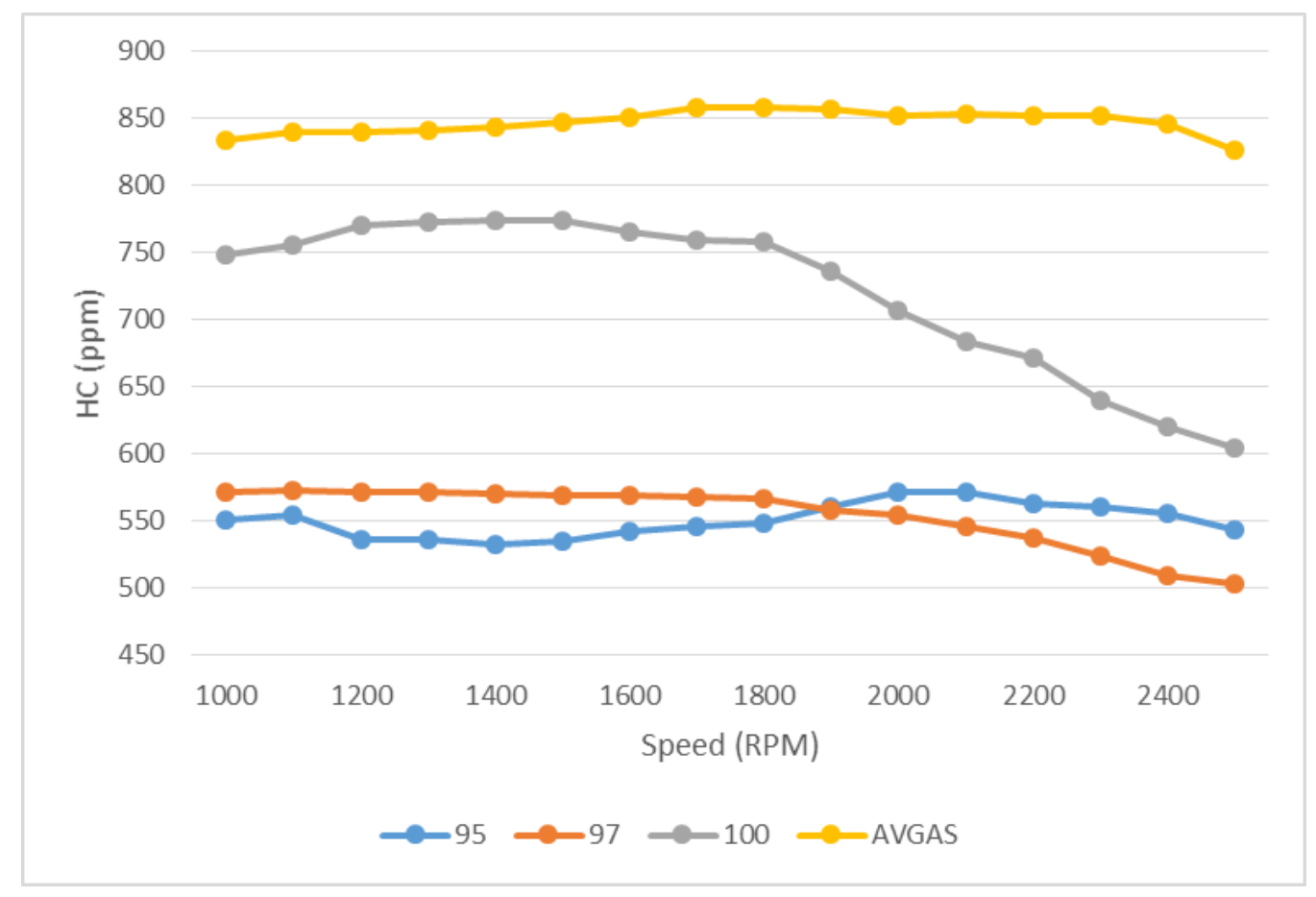

Figure 3.2: Variation of hydrocarbon (HC) emission with engine speed

Figure 3.2 shows engine speed versus variations in the unburned $\mathrm{HC}$ emissions during the operation of the engine. $\mathrm{HC}$ emissions from piston engines was the result of several factors such as unburnt or partially burnt fuels, incomplete combustion and the presence of lubricating engine oil in the fuel or combustion chamber.

For the HC emission, the results indicated that the piston engine when fuelled with RON100 MOGAS generated higher emissions of HC gas compared to RON fuels while RON95 MOGAS generates the lowest HC emission. Standard 100LL AVGAS generates the highest HC exhaust gas among all the fuels tested. As the speed increased, the value of $\mathrm{HC}$ emission in the exhaust gas was significantly reduced for all the fuels. It indicates that $\mathrm{HC}$ emissions decrease with increasing engine power. In addition, HC concentrations in the exhaust gas also can be influenced by the temperature of the fuel-to-air (F/A) mixture as it enters the combustion chamber, so large changes in ambient temperature could have an effect. 


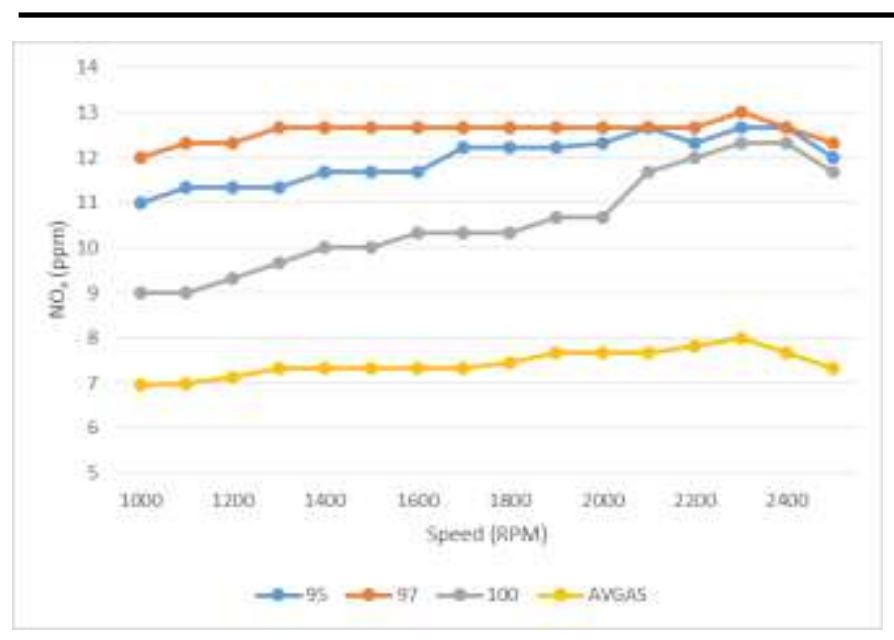

Figure 3.3 Variation of nitrogen oxide (NOx) emission with engine speed

Figure 3.3 shows engine speed versus variations in the of nitrogen oxide (NOx) emission. As demonstrated in Figure 3.3 NOX emissions are highest at cruise, decreasing in the following order: cruise $\rightarrow$ take-off $\rightarrow$ taxi $\rightarrow$ idle. This order shows that fuel to air ratio at cruise is the lowest and is the highest at idle. The rate of NOX formation was found to be directly dependent on the cylinder temperature. This is because nitrogen only reacts with oxygen when there is higher temperature present. The generation of NOX was lowest for RON100 fuel compared to RON95 and RON97 fuels. A decrease in NOx emissions for RON100 was due to the requirement for a longer combustion period to achieve higher combustion efficiency. This is well explained when standard 100LL AVGAS produces lowest NOX emission among all the tested fuel.

\section{CONCLUSION}

The exhaust gas emission of aviation engine was tested using various fuels with different octane rating. An analysis of the experimental results under the same engine specifications and operations led to the following conclusions. The RON100 fuel reduced the NOX emission compared to RON95 RON97 fuels. This was mainly due to the fact that higher octane rating fuels has higher efficiency in aviation engines. Piston engines are designed to utilize higher octane rating fuels to avoid detonation. Besides, RON100 fuel produced the highest HC emission compared to RON97 and RON95 fuels. This shows that the HC emission increases as the octane rating of the fuel increased. The $\mathrm{CO}$ emission was found to be higher for RON100 fuel compared to RON97 and RON95 fuels. Engine design plays an important factor as aviation engines are design for aviation gasoline than motor gasoline to withstand higher compression for more power output and to avoid detonation. From the results obtained it can be said that gasoline with higher octane rating increase the concentration of $\mathrm{HC}$ and $\mathrm{CO}$ in the exhaust gas. It can be concluded that RON100 has the nearest emission rating when compared to standard 100LL AVGAS. Usage of motor gasoline in aviation engine can be considered if not for the octane rating which can affect the engine efficiency.

\section{ACKNOWLEDGEMENT}

I would like to extend my gratitude to God for giving me the chance, patience and strength to complete this thesis. In particular, I wish to express my sincere appreciation to my supervisor, Prof. Dr. Rahmat Mohsin for his guidance, encouragement, critics, consistent supervisions and motivation. Without his continued support, this thesis would not have been the same as presented here. In preparing the proposal, I was contact with post-graduates student, Mr. Thanikasalam Kumar. He have contributed towards my understanding, skills and thoughts. Furthermore I would also like to acknowledge with much appreciation the crucial role of the lab assistant Mr.Zaid who invested a lot of time in guiding me to use all the required equipment in completing my project. I am also very thankful to Universiti Teknologi Malaysia (UTM) for providing me all of equipment and materials needed to complete my research. . Next, my most gratitude to my beloved mother for kept supporting and praying the best for me. Last but not least, I would to express my sincere thankful to my close friends for their continuous support and endless attention.

\section{REFERENCES}

[1] Unleaded AVGAS Transition Aviation Rulemaking Committee. 2012. FAA UAT ARC final report part I body. Washington, D.C.: Federal Aviation Administration.

[2] Energy Commission of Malaysia. 2016. Malaysia Energy Statistics Handbook 2016. Kuala Lumpur: Energy Commission of Malaysia.

[3] LTD, J. A. 2011. Alcohol, Lead, Compression Ratio: Fuel Guidance. Queensland, Australia: JABIRU AIRCRAFT PTY LTD.

[4] Gerberding, J.L. 2005. Preventing Lead Poisoning in Young Children. USA: U.S. Department of Health and Human Services, Public Health Service.

[5] Rouse, P. 2009. Why Does My Airplane Smell Like It Has Been Drinking? Safety first for general aviation, 28-29.

[6] Rindlisbacher, T. 2007. Aircraft Piston Engine Emissions Summary Report. Switzerland: Federal Department of the Environment, Transport, Energy and Communications DETEC Federal Office of Civil Aviation FOCA Aviation Policy and Strategy Environmental Affairs.

[7] Greenberger, M. A. 2016. F O R E W O R D : Exhaust Emissions from InUse General Aviation Aircraft :ACRP 164 Research Report. Exhaust Emissions from In-Use General Aviation Aircraft. United States of America: National Academy of Sciences.

[8] DYNO mite Dynamometer. 2008.

[9] Mohsin, R., Majid, Z.A., Nasri, N.S., Sharer, Z. 2014. Effect of biodiesel blends on engine performance and exhaust emission. Energy Conversion and Management, 821-828. 